\title{
Familial aggregation of breast/ovarian cancer: age of onset along subsequent generations in Brazil
}

\author{
Agregação familiar de câncer de mama \\ e ovário: idade de manifestação \\ em gerações subseqüentes no Brasil
}

Rosalina Jorge Koifman 1

Sergi o Koifman 1

Roberto José da Silva Vieira 2

\footnotetext{
1 Departamento de Epidemiologia, Escola Nacional de Saúde Pública, Fundação Oswaldo Cruz. Rua Leopol do Bulhões 1480, Rio de Janeiro, RJ 21041-210, Brasil. 2 Instituto Fernandes Figueira, Fundação Oswaldo Cruz. Av. Rui Barbosa 716 Rio de Janeiro, RJ 22250-020, Brasil. koifman@dcc001.cict.fiocruz.br
}

\begin{abstract}
Antecedents of familial aggregation of breast and ovarian cancer are observed in only $5-8 \%$ of all breast cancer cases. Neverthel ess, this variable displays one of the highest risk ratios associated to breast cancer outcome. Despite recent identification of genetic mutations associated with familial aggregation of these tumors, mainly at BRCA1 and BRCA2 genes, knowledge on the interaction between environmental agents in these families remains quite unclear. In this paper we ascertained the correl ation among ages of the onset of breast/ovarian cancer in 260 Brazilian families with those cancer aggregation. Further we estimated the median age of the onset of breast cancer among four generations. Weobserved that the hi gher the number of family cancer cases, the highest is the correl ation of ages for the onset of breast cancer. We also observed a 8-10 year decline in the mean age-of-onset of breast/ovarian cancer from one generation to another in the studied families. If these resul ts could be confirmed el sewhere, we bel ieve that the hypothesis of interaction between environmental risks factors in families indeed showing breast/ovarian cancer aggregation is reinforced.
\end{abstract}

Key words Neoplasm; Breast; Ovary, Ovarian; Genetics

Resumo A presença de antecedentes de agregação familiar de câncer de mama e ovário é observada em apenas $5 \%$ a $8 \%$ de todos os casos de câncer de mama. Esta variável, entretanto, é uma das que apresenta maior razão de ri scos para o desfecho câncer de mama. Apesar da identificação recente de mutações genéti cas associadas com a agregação familiar destes tumores, sobre tu do nos genes BRCA1 e BRCA2, o conhecimento sobre as interações entre fatores ambientai s e genéti cos nessas famílias permanece rel ati vamente obscu ro. Neste trabal ho, determinamos a correlação dasidades de início de câncer de mama e ovário em 260 famíli as com agrupação daqueles tumores. Posteri ormente, foi estimada a idade média de início destes tumores ao longo de quatro gerações. Observou-se que quanto maior o número de casos de câncer na família, mai or o coefi ci ente de correl ação entre as idades de iníci o destes cânceres. Foi também constatado um declínio deoito a dez anosna idade média de início do câncer nessas famílias ao longo de três gerações. Os autores acreditam que, se esses resultados forem confirmados por outras investi gações, reforça-se a hipótese de uma interação entre fatores ambientais e genéti cos no desencadeamento dos tumores de mama e ovário em famílias quejá apresentam uma forte agregação desses tumores.

Palavras-chave Neoplasia; Mama; Ovário; Genética 


\section{Introduction}

Breast cancer has been a leading cause of cancer among women in developed countries, showing an increasing incidence and stable mortality during the last decades (Garfinkel et al., 1994). Among the known risk factors associated to that disease, familial aggregation of female breast cancer has been identified as an important condition yielding to increased risk of developing that tumor. Antecedents of first degree relatives affected with breast cancer ranges from $8 \%$ to $30 \%$ among cases with such history (Anderson \& Badzioch, 1985; Dawson \& Thompson, 1989; Marcus et al., 1996). Indeed, risk ratios as high as 5 has been mentioned among women with previous cases of breast cancer among close relatives, such as a mother or a sister, as compared with women without family antecedents of that neoplasm (Kelsey, 1993). For instance, if just a woman's mother has had breast cancer, her relative risk to develop the same cancer is 1.8; if one sister has had the disease, the risk is quite higher, 2.5; moreover, if both mother and sister had developed breast cancer, the risk jumps to 5.6 (Bain et al., 1980). The reasons involved in this process remained quite unclear until the last few years when knowledge about the genetics of breast cancer experienced a remarkable improvement.

Familial breast cancer is now known to develop in multiple family relatives among subsequent generations, very often bilateral, and at relatively young ages. Up to now, some genes were identified as having an important role in familial aggregation of breast cancer. At first, the gene named BRCAl (for breast cancer) located in chromosome 17 had been implicated in cancer expression of families displaying female breast and ovarian cancer (Hall et al., 1990). More than eighty mutations in this gene were described, despite the fact that the importance of most of them remains unknown. Another gene involved in familial aggregation of breast cancer is BRCA2 located at chromosome 13 , and mainly associated with cases of male breast cancer and ovarian cancer in the same families. The existence of a third gene, still unidentified, yet named BRCA3, was discussed taking into account observation of family cases of breast and ovarian cancer without showing mutations either on BRCA1 or BRCA2. As a whole, BRCA1 and BRCA2 (or even BRCA3 if further identified) seems to play the most important role in familial aggregation of breast and ovarian cancer cases, while 553 gene seems to be more involved in the expression of spo- radic breast cancer cases (Elledge \& MacGuire, 1994; Ozbun \& Butel, 1995). Nevertheless, p53 gene was also described in Li-Fraumeni families (Malkin et al., 1990).

The manner in which genetic and environmental risk factors act during carcinogenesis either on familial aggregation and sporadic breast cancer remains unclear. Therefore, efforts have been made trying to improve understanding of their possible interaction by describing patterns of disease spreading among populations. Early menarche, late menopause, declining parity and consumption of oral contraceptives during adolescence before a fullterm pregnancy, were also pointed out as variables possibly associated with breast cancer related to a pattern of high exposure to estrogens during the reproductive years (Kelsey, 1993; Newcomb et al., 1996). Nevertheless, these variables seems to act differently if cases are sporadic or family aggregated (Colditz et al., 1996).

Among variables associated to breast cancer, age is perhaps one of the best documented in literature. Breast cancer in different populations show quite similar distributions by age, with sharp increases on incidence rates between 25 and $45 \mathrm{yr}$. old, followed by a slower increasing speed on incidence after that age. Indeed, this observation has been pointed out as a strong indicator of hormonal involvement in breast cancer development. Therefore, breast cancer is mainly a post-menopausal disease, affecting around $4 \%$ of women below $35 \mathrm{yrs}$. old (Chung et al., 1996) and 7\% below 40 yrs. old (Winchester, 1996). The majority of cases are diagnosed between 45 and $55 \mathrm{yrs}$. old in the USA, and only $20 \%$ among women $75 \mathrm{yrs}$. or older (Busch et al., 1996). One of the most interesting findings recently mentioned in the literature about age distribution of breast cancer is the decline in the age of onset among breast cancer cases observed during the last decades.

Different studies have shown that age of onset among families with several cases of breast cancer usually start at younger ages than observed among sporadic cases in the general population (Dotto, 1985). Nevertheless, the manner in which cases from families with antecedents of breast and ovarian cancer behavior has been poorly documented in the literature with regard to age distribution among successive generations.

In this paper we will present data on the age of onset of breast/ ovarian cancer among Brazilian families showing several cases of both tumors identified among different generations. 
Implications of the observed trends will be further commented on with consideration to available knowledge in the literature.

\section{Methods}

Since 1994, the Brazilian National DNA Bank Program (BNDBP) has been gathering blood samples and epidemiological information from families showing aggregation of breast and ovarian cancer in different cities. At first Rio de Janeiro, São Paulo and Porto Alegre were included, with this list increasing with time. Blood samples have been used to identify genetic mutations, which will be further linked to epidemiological data aiming to analyze possible patterns of their distribution among these families. In this paper, we will present epidemiological information on the distribution of age for the onset among cases of breast/ ovarian cancer identified among families with 3 or more breast/ ovarian cancer cases in the three aforementioned cities.

At first, Pearson's correlation coefficients between ages of onset of breast/ ovarian cancer among enrolled women in BNDBP was carried out. Furthermore, distribution on the ages of the onset of breast/ ovarian cancer was ascertained among subsequent generations in the same families. These ages were determined towards the median age of onset in each generation for each family, as a measure to guarantee the same probability for all families to be represented, regardless of the number of affected women in each family.

\section{Results and discussion}

Among enrolled families in BNDBP, 260 have two or more cases of breast/ ovarian cancer in Rio de Janeiro and São Paulo, 64 of them with 4 or more cases. Median age at diagnosis among enrolled cases with 4 or more family cases was 52 yr. and 48 yr. among their close relatives.

As seen in Table 1, a high correlation of age at the onset between close relatives of cancerous enrolled women was observed: $r=0.95$ (0.81-0.99), $F_{1 ; 9}=81.2, p \nless 0.005$. Correlation of age at the onset among close relatives of noncancerous enrolled women with multiple family cases (4 or more) was also high, $r=$ 0.79 (0.59-0.80), $F_{1 ; 82}=84.0, p \nless 0.005$. Among non cancerous en rolled women with 3 or less family cases, the correlation coefficient was moderate, $r=0.43$ (0.33-0.53), $F_{1 ; 257}=59.3$, $\mathrm{p} \lessdot 0.005$.

These results suggest a strong correlation between ages at onset of breast and ovarian cancer among relatives from families with past family antecedents of these tumor sites. Moreover, the higher the number of family cases, the higher correlation was observed between ages of breast and ovarian cancer onset. Nevertheless, these results are not informative on directionality or timing about ages of onset, and they just indicate similarity between these ages among all studied families. In other words, they just reveal an important closeness or similarity between age groups in which cases were diagnosed among families with past antecedents of breast/ ovarian cancer.

To analyze time trends on the age of onset of breast/ ovarian cancer, Table 2 is more useful: when distribution of ages of the onset of breast and ovarian cancer was carried out along subsequent generations, a decline on the mean age of onset was observed: $53.4 \mathrm{yr}$. in the first generation of affected women, $43.3 \mathrm{yr}$. in the second, $34.6 \mathrm{yr}$. in the third and $30.5 \mathrm{yr}$. in the fourth ( $F=30.85 ; p \varangle 0.00001$ ). These results - obtained towards several intra-family comparisons along subsequent generations of close relatives -, suggest a marked decline among ages in which these tumors were diagnosed, i.e., a 8-10 years decline between two subsequent generations considering the first three ones.

Distribution of cases of breast/ovarian cancer among enrolled families, Brazilian $\mathrm{N}$ ational DN A Bank Program.

\begin{tabular}{lcccc}
\hline & $r$ & $95 \%$ C.I. & $F$ & $p$ value \\
\hline Close relatives of affected women & 0.95 & $0.81-0.99$ & 81.2 & $<0.005$ \\
$\begin{array}{l}\text { Close relatives of non-affected } \\
\text { 4 or more family cases }\end{array}$ & 0.79 & $0.59-0.80$ & 84.0 & $<0.005$ \\
3 or less family cases & 0.43 & $0.33-0.53$ & 59.3 & $<0.005$ \\
\hline
\end{tabular}


Table 2

Age of onset of breast/ovarian cancer along family generations*, selected brazilian cities**.

\begin{tabular}{lcccccc}
\hline Generation & $\begin{array}{c}\text { Families } \\
(\mathrm{n})\end{array}$ & $\begin{array}{c}\text { Mean age } \\
\text { (years) }\end{array}$ & $\begin{array}{c}\text { Standard error } \\
\text { (years) }\end{array}$ & $\begin{array}{c}\text { 1st quartile } \\
\text { (years) }\end{array}$ & $\begin{array}{c}\text { Median } \\
\text { (years) }\end{array}$ & $\begin{array}{c}\text { 3rd quartile } \\
\text { (years) }\end{array}$ \\
\hline First & 100 & 53.4 & 1.1 & 46.0 & 50.0 & 60.0 \\
Second & 100 & 43.3 & 0.9 & 38.0 & 43.0 & 50.0 \\
Third & 25 & 34.6 & 1.8 & 27.0 & 33.0 & 38.0 \\
Fourth & 2 & $30.5 * *$ & 1.5 & 29.0 & 30.5 & 32.0 \\
\hline
\end{tabular}

* At least two generations of affected women and 3 or more cases of breast/ovarian cancer.

** Rio de J aneiro, São Paulo and Porto Alegre.

*** $\mathrm{F}=30.85, \mathrm{p}<0.00001$.

These results should be interpreted cautiously, because they may be biased in the sense that women in the first generation had experienced a higher life span than those in the third or the fourth generation, who still are in their 30's or 40's. Therefore, as their follow up goes on, cases at older ages will certainly be diagnosed, increasing the mean age of onset in the respective third and fourth family generation. Moreover, mamography access may also allow breast cancer detection at earlier ages, changing the mean age-of-onset of breast cancer among different generations. Henceforth, we believe that a continuous follow up of these women should yield to closer mean ages at the onset of breast/ ovarian cancer than the time interval now observed (8-10 years between subsequent generations). Nevertheless, we also consider these intervals so large, that it seems quite improbable that lifelong correction of ages at the onset, brought by a continuous follow up, could eliminate the current differences observed among women in subsequent generations.

Consequently, we believe that present results may indeed point out a true trend towards a decline in the age of the onset of breast/ ovarian cancer diagnosed among women from families with a strong pattern of these tumors aggregation. Therefore, a comprehensive analyses taking into account the role of environmental risk factors to breast and ovarian cancer among families showing this tumor aggregation pattern in contemporary societies should be explored. Unfortunately, the majority of epidemiological studies analyzing family aggregation of breast cancer have still been just oriented towards the important genetic aspects involved in this process, and not considering the probable role of environmental risk factors in their expression.

\section{Conclusions}

A sample of Brazilian families showing a pattern of breast and ovarian cancer aggregation was studied. A statistically significant 8 to 10 $y r$. decline on the mean age of the onset of breast/ ovarian cancer among their close relatives was observed along three subsequent generations.

\section{References}

ANDERSON, D. E. \& BADZIOCH, M. D., 1985. Risk of familial breast cancer. Cancer, 56:383-387.

BAIN, C.; SPEIZER, F. E.; ROSNER, B.; BELANGER, C. \& HENNEKENS, C. H., 1980. Family history of breast cancer as a risk indicator for the disease. American Journal of Epidemiology, 111:301-308.

BUSCH, E.; KEMENY, M.; FREM GEN, A.; OSTEEN, R. T.; WINCHESTER, D. P. \& CLIVE, R. E., 1996. Patterns of breast cancer care in the elderly. Cancer, 78:101-111. 
CHUNG, M.; CHANG, H. R.; BLAND, K. I. \& WANEBO, H. J., 1996. Younger women with breast carcinoma have a poorer prognosis than older women. Cancer, 77:97-103.

COLDITZ, G. A.; ROSNER, B. A. \& SPEIZER, F. E., 1996. Risk factors for breast cancer according to family history of breast cancer. Journal of the National Cancer Institute, 88:365-371.

DAWSON, D. A. \& THOMPSON, G. B., 1989. Breast cancer risk factors and screening: United States 1987. National Center for Health Statistics. Vital Health Statistics, 10:1-60.

DOTTO, J. E., 1985. Bilateral cancer of the breast. Revista Argentina de Mastología, 4:13-18.

ELLEDGE, R. M. \& MACGUIRE, W. L., 1994. The p53 tumor supressor gene in breast cancer. Breast Cancer Research, 32:39-47.

GARFIN KEL, L.; BORING, C. C. \& HEATH, C. W., 1994. Changing trends: an overview of breast cancer incidence and mortality. Cancer, 74:222-227.

HALL, J. M .; LEE, M. K.; NEWMAN, B.; MORROW, D. E.; ANDERSON, L. A.; HUEY, B. \& KING, M. C., 1990. Linkage of early onset familial breast cancer to chromosome 17q21. Science, 250:1684-1689.
KELSEY, J. L., 1993. Breast cancer epidemiology: summary and future directions. Epidemiologic Reviews, 15:7-16.

MALKIN, D.; LI, F. P.; STRONG, L. C.; FRAUMENI J r., J. F.; NELSON, C. E.; KIM, D. H.; KASSEL, J.; GRYKA, M. A.; BISCHOFF, F. Z.; TAINSKY, M. A. \& FRIEND, S. H., 1990. Germ line $\mathrm{p} 53$ mutations in a familial syndrome of breast cancer, sarcomas, and other neoplasms. Science, 250:1233-1238.

MARCUS, J. N.; WATSON, P.; PAGE, D. L.; NAROD, J.A.; LENOIR, G. M.; TONIN, P.; LINDER-STEPHENSON, L.; SALERNO, G.; CONWAY, T. A. \& LYNCH, H. T., 1996. Hereditary breast cancer: pathobiology, prognosis, and BRCA1 and BRCA2 gene likage. Cancer, 77:697- 709.

NEWCOMB, P. A.; STORER, B. E.; LONGNECKER, M. P.; MITTENDORF, R.; GREENBERG, E. R. \&WILLET, W. C., 1996. Pregnancy termination in relation to risk of breast cancer. JAM A, 275:283-287.

OZBUN, M. A. \& BUTEL, J. S., 1995. Tumor supressor p53 mutations and breast cancer: a critical analysis. Advances in Cancer Research, 66:71-141.

WINCHESTER, D. P., 1996. Breast cancer in young women. Surgical Clinics of North America, 76: 279-287. 